\title{
Transitions without Transitional Justice in Asia
}

\author{
Sung Chull Kim
}

\begin{abstract}
This article addresses the underexplored question of why some state violence cases in Asia are not followed by transitional justice even during a democratic transition. It explicates the two factors that obstruct or delay seeking truth and accountability and thus bring impunity for perpetrators. One is the context in which the violence took place, and the other is longevity of the violent regime. If the violence occurs during a period of conflation of state construction and regime building, and if the perpetrators' power persists long enough to be institutionalized, transitional justice is least likely to take place. Five cases of violence violence which were committed by anticommunist regimes during the Cold War in four Asian countries are explored.
\end{abstract}

Keywords context of violence, longevity of regime, transitional justice, democratic transition, state construction, regime building

\section{Introduction}

Incidents of state violence in Asia that occurred under military authoritarian rule during the Cold War have begun to receive public and academic attention over the last three decades. Some cases have gone through resolution processes, including truth-finding, to deal with accountability, awards of compensation, trials, amnesty, or a combination of all or some of these aspects. But other cases have never been resolved. What demands our particular attention is that these unresolved cases took place in countries that are experiencing democratization. For instance, there has been no progress in bringing to justice the perpetrators of the mass killings that took place during the Korean counterinsurgency operations at the end of 1940s and the early 1950s on Jeju island, the Indonesian counterinsurgency in the 1960s, and the Thai "red drum" killings in Phatthalung area in the early 1970s, despite significant progress in democratization later on in these countries.

What is the relationship between transitional justice for past state violence 
and democratic transition? It is difficult to generalize the cause-and-effect relationship; however, it is fair to say that democratic transition from authoritarian rule-or the democratization process-involves various political changes which create a friendly environment for transitional justice and the resolution of past violence.

The notion of democratic transition is more inclusive than that of transitional justice, although democratic transition per se does not necessarily bring about transitional justice. Democratic transition involves a regime change, including substantive political changes moving in a democratic direction. One of the most important initial steps toward democracy is a power shift either through an unprecedentedly fair election or through a pact between the ruler and the opposition. Democratic transition is mostly a toilsome process whereby a new regime has to phase out legacies and practices that the outgoing oppressive regime, and preceding repressive regimes, must leave behind: violence, surveillance, secrecy, election fraud, corruption, censorship, abuse of power, distrust, etc. The speed and length of the process of democratic transition depends on various factors such as balance of power, international pressure, and the diffusion effect. Transitional justice, which is expected to take place in this transitional period, deals with the past violence and human rights abuses, whether they happened under the outgoing oppressive regime or preceding regimes.

It is also worth noting that democratic transition is not the only notion that is associated with transitional justice. Post-conflict peacebuilding may harness transitional justice. Witnessing the mass violence in Rwanda, Yugoslavia, and Cambodia, observers have paid special attention to transitional justice as one of the many subjects of institutionalizing and consolidating peace in post-conflict societies (Jeffery and Kim 2014, 3-8). Transitional justice in this context is part of the broader process of the establishment of peace. Transitional justice proceeds along with other peacebuilding efforts such as disarmament and rehabilitation of ex-soldiers, development aid, national and local elections, etc. Inasmuch as postconflict peacebuilding is assisted by, and sometimes initiated by, the international community, transitional justice is normally on the menu of the international projects. Most cases of transitional justice in peacebuilding are not self-generating in the conflict-torn societies but facilitated, financed, and staffed by international actors (for critical studies, see Sriram 2007; Peou 2014).

In contrast, democratic transition from authoritarian rule is basically a domestically-generated change, even if the change in some cases is prodded by international support or pressure. Thus "transitions without transitional justice" - which I dub here to highlight a discrepancy between democratic transition and transitional justice-necessitates addressing the question of why some cases of democratic transition do pass by the past violence without enacting truth-finding missions to ensure accountability. This question is legitimated because democratization usually supposes the admission of old wrongdoings and 
establishment of human rights, as well as institutionalization of civilian rules and procedures.

Acknowledging the above-mentioned difference of the context between the post-conflict peacebuilding and transition from non-democratic rule, this article examines the reasons for the cases of the absence of transitional justice in the democratic transition. The purpose of this article is to uncover the causal sources that cancel out a possibility of justice at the time of democratic transition. The central argument of this article is: if violence occurs during a period of conflation of state construction and regime building, and if the perpetrators' power (and the repressive regime's power) persists long enough for it to be institutionalized, efforts to find truths and ensure accountability regarding the past violence will encounter difficulties even if they take place during the democratization process.

The article selects five Asian cases of violence: Imperial Japan's mass suicide/ killing of its own citizens (1945), two Korean cases of state violence (1947-1954, and 1980), the Indonesian mass killings during the counterinsurgency operations (1965-1968), and Thailand's "red drum" killings (1971-1975). The rationale of the selection is that, first, in all of the cases, violence was committed by anticommunist regimes and justified by the Cold War divide; second, each case is representative in terms of scale of violence, ramifications, and socio-political impact; third, the violence was, at least, addressed in one way or the other during the democratic transition, whether transitional justice was satisfactory to the victims or obstructed for any reasons; finally, because of the above-mentioned rationale, these cases have some implications for analytical and empirical examinations of cases in other regions.

My analysis of the two factors with regard to transitional justice might be applied to cases in Latin America or even in the process of post-conflict peacebuilding, but I limit my analysis to those Asian cases due to the limitations of my knowledge and space considerations.

The article, first, begins by raising a conceptual question of why some cases of democratic transition pass by past violence; second, explicates in detail two factors which obstruct or delay transitional justice during democratic transition; third, examines the five cases through the conceptual lenses; and finally, draws a conclusion.

\section{Conceptual Question: Why Do Democratic Transitions Pass by Past Violence?}

By definition, transitional justice is the confronting of the wrongdoings of previous repressive regimes particularly in times of political transition (Teitel 2003). Transitional justice involves various judicial and non-judicial measures that address human rights abuses. Measures to be taken include reparations, 
truth-finding commissions, prosecution and trials, amnesty, pardon, reconciliation, and institutional reforms. For an analytic purpose, however, this article limits the scope of the definition. Here transitional justice is narrowly defined by emphasizing truth-finding and accountability as the core components. Transitional justice involves, first, seeking truths about the violence (particularly the perpetrators' act) and, second, demanding and ensuring accountability (acceptance of responsibility for the result of violence). Truth-finding may take place either during prosecution and trial or through a truth-finding commission; and accountability may be demanded and ensured either in the judicial process, through the truth-finding commission, or through a reconciliation commission. This article emphasizes both finding truth and ensuring accountability, regardless of the formality of the measures in which the two crucial elements are instituted. Pardon or amnesty is the step that must follow truth-finding and accountability. That is, they may be part of the process of achieving transitional justice at a later stage, but truth-finding and accountability must precede it. By definition in this article, truth-finding and accountability are a necessary condition of successful transitional justice.

There is a body of literature that examines the question of how transitional justice takes place, whereas there have been no such efforts to address the question of why a democratic transition addresses or does not address past violence. On the question of how, there are explanations on the two approaches of transitional justice: the punitive approach to punish offenders, and the reconciliatory approach to integrate perpetrators into the new society (Amstutz 2006, 165-68). In detail, advocates of retributive justice focus more on trial more so than other measures such as repentance, reparation, pardon, or amnesty. Only after dealing with the issue of whom to punish and what to punish can reconciliation between the perpetrators, on the one hand, and the victims and the society more broadly, on the other, be justified. Retributive justice is less concerned with order and harmony in the new society than the price of the crimes against human rights. There is little room for forgiveness of the perpetrators and their reintegration into society (Bell and Campbell 2004).

Restorative or reconciliatory justice prioritizes a transformative effect in relation to victims, perpetrators, and the society as a whole. It focuses on the gradual achievement of justice: ideally speaking, it should start with truth-finding through a truth commission and then move to either trial or amnesty on a case by case basis. That is, restorative justice, while seeking truths and demanding accountability, ends up with forbearance and social unity, and for this reason it is frequently called reconciliatory justice. Restorative justice for past violence aims at attitudinal or behavioral change by offenders, thus reintegrating them into a new society. Restorative justice presupposes mutual respect and recognition between previous enemies and requires recognition of the dignity of others; in this regard, it is considered a holistic approach (Boraine 2006). But this holistic 
approach also has its limitations in the real world. If the transformative effect is overemphasized, then the resolution of past violence is likely to become a soft option without extensive truth-finding and accountability (Ashworth 2002; Verdeja 2009, 3; Lutz and Reiger 2009, 275-93).

Whichever approach a transitional society may adopt in the transitional period, seeking truths and demanding accountability are the core components. Neither approach allows impunity particularly through blind amnesty. The main difference is that retributive justice is teaching, whereas restorative justice is transformative. Retributive justice technically focuses on punishing perpetrators and imparting the lesson of stern rule of law on violence, whereas restorative justice aims at transforming the relationship between perpetrators and victims and intends to build institutions of justice (Kritz 1995; Marshall 1999; Abu-Nimer 2001; Cho 2007; Lundy and McGovern 2008).

What has mattered in this discussion about the two approaches is not an issue of moral superiority or inferiority, but the question of preference, or frequency, in the real world. Indeed, a flourishing number of case studies, focused on the approaches of transitional justice, have demonstrated that a majority of the cases of dealing with the past wrongdoings ended up with restorative justice (Amstutz 2006, 153; Philpott 2006; Clarke 2009; Parent 2010). Using collected data, Olsen, Payne, and Reiter (2010) have made some of the most useful generalizations about conditions and paths of transitional justice: first, length of the authoritarian legacy matters; second, the economic situation affects the choice of mechanisms such as trial, amnesty, truth commission, etc.; and third, the form of transition affects the choice of mechanism. They have argued that so-called balanced justice-a combination of the mechanisms of both retributive justice and reconciliatory measures-contributes to the strengthening of democracy and human rights in times of transition. Their analysis empirically proves a middle ground of the two competing scholarships regarding transitional justice: the punitive justice based on legalism and the restorative justice based on pragmatism (for the competing scholarship, see Vinjamuri and Snyder 2004).

Other scholars have delved into the question of what determines the approach or path in detail-ether trials or non-judicial track. Skaar (1999) has focused on balance of power between the outgoing elite and the public in the new regime. The more power the public in the new regime holds, the higher the chance of trials; and the truth commission is a choice when power is balanced between the two. In a similar vein, Duthie (2009) and Fernandez-Torne (2017, 15-26) have paid special attention to the role of civil society in the truth commission formation, reparation programs, and tribunals. As opposed to these scholars' concentration on domestic forces, Kim (2012) and Hirsch (2014) have explored and proved empirically the international impact, that is, transnational networks and diffusion of norms.

The above-mentioned discussions have focused on the conditions or 
Table 1. Likelihood of Transitional Justice

\begin{tabular}{c|c|c|c}
\hline \hline \multicolumn{2}{c|}{} & \multicolumn{2}{c}{ Conflation of State Construction and Regime Building } \\
\cline { 2 - 4 } \multicolumn{2}{c|}{} & Yes & No \\
\hline $\begin{array}{c}\text { Duration of Violent } \\
\text { Regime }\end{array}$ & Long & Obstructed TJ & Unsuccessful TJ \\
\cline { 2 - 4 } & Short & Unsuccessful TJ & Successful TJ \\
\hline
\end{tabular}

Source: Author

determinants of diverging approaches and paths in transitional justice. Despite their own merits, they have missed addressing the question of why some states experiencing democratic transition do not undergo transitional justice, particularly proper truth-finding and accountability. That is, the independent variables of those unfortunate cases have not been identified.

If democratic transition is proved not to be a sufficient condition for transitional justice, it would be natural for us to delve into further questions that are related to the period prior to democratic transition. Suggestive questions are: how violence was dealt with prior to the transitional period, and, tracing back to the time of violence, in what context the violence took place and what the perpetrators intended with it. These questions involve identifying the original context of violence and the violent regime's (or successor regime's) handling of the past. The first one pertains to identifying the context, and the second concerns the post-violence period. I fill this knowledge gap by explicating two factors that act as impediments to seeking truths and ensuring accountability in some Asian cases. One factor is the conflation of state construction and regime building, and the other factor is the relative longevity of the regime that committed the violence or its successor regime (see Table 1).

As for the first factor, I bear in mind that many post-colonial Asian countries have undergone competition and struggle among groups with different ethnic, religious, and/or ideological backgrounds during the critical period of constructing an independent state and a new regime simultaneously. This kind of conflation of state construction and regime building is associated with the particular nature of violence, and the mass killings committed in this period are addressed later. The violence is categorical and uncompromising in nature, and it is directly related to the foundation of the state as well as legitimacy of the firstever regime. As to the second factor, which is not necessarily connected to the first factor, I bear in mind that the duration of the violent regime is normally followed by legitimation of that brutal act and elimination of the collective memory about it.

Table 1 shows that if the two factors are combined, a transitional society dealing with past violence finds itself facing the worst outcome: "obstructed transitional justice," in which the efforts for finding truth are blocked or aborted 
for different reasons in each case. If one of the two factors is at work, a transitional society will face "unsuccessful transitional justice," in which truth-finding efforts are not welcomed and thus accountability is hard to achieve. "Successful transitional justice" is likely to occur when the following conditions are met: the violence did not take place in the period of conflation of state construction and regime building, and the violent regime is short-lived, for example, less than about thirty years. In this article, a thirty-year span, which is normally considered one biological generation, is a baseline point of dividing long-lived regimes from short-lived ones.

\section{Conflation of State Construction and Regime Building}

From an analytical point of view, state construction differs from regime building, but there has not been a sustained study on this topic. State construction involves the expansion of power over territory and diverse social elements, as well as the establishment of apparatuses and institutions, whereas regime building consists of the establishment of rules and orders regarding the relationship between the rulers and the ruled. In reality, in a new state, state construction and regime building take place simultaneously. In Asia and Africa after the end of World War II, many societies threw off the yoke of empire and underwent their own independent state construction and regime building processes (Mengisteab 1997; Aspinall and Berger 2001; Abbay 2004).

State construction is a process of establishing statehood that consists of population, territory, and sovereignty. Externally, state construction begins with independence of statehood from external forces and involves the business of protecting the individuality of the state. The meaning of independence is particularly true in the non-western world. This is so because, as Jackson and Rosberg (1982) aptly note, in that world, state construction in terms of jurisdiction and international recognition preceded the internal process of forming a state. The formation of Westphalian states in Europe began with the line of nations, a process that is called nation-state formation, whereas state construction in Asia, and in Africa as well, began with liberation from the colonial rulers and with international recognition, even before the process of internally forming statehood. Even after international recognition of its statehood, therefore, state construction was an arduous process of struggles of exclusion and inclusion of certain nations or ethnic groups, a process that frequently involved instability and violence.

State construction commonly requires the exercise of power to build up a bureaucracy, a tax system, and the military. In this process, many Asian countries, with the notable exceptions of mainland China and Japan, modeled themselves on their former colonial masters. Even those people who had fought the colonial 
rulers relied on the vestiges of colonial states (Mamdani 2001; Cole and Kandiyoti 2002; Young 2004). Myanmar's Aung San and Korea's Syngman Rhee are typical examples. Also, state construction in this case involved top-down penetration of power into all territorial, social, and ethnic peripheries.

The construction of the new state was coupled with the first-ever regime building process. Regime connotes the political form of the state. There are many types of regimes. To name a few, authoritarian regime, military regime, monarchy, autocracy, and democracy are regime types. A regime has its own way of forming particular norms of ruling, legitimizing its rule, and disseminating a unique code of national security and public safety; in addition, it maintains particular rules for power succession or replacement. Once a regime is built, it may endure for a certain period of time. But the regime is normally changed and transformed, and an abrupt change of the regime is revolution or coup, a significant topic of analysis in the social sciences. While a state may persist, the regime may change over time.

Whereas state construction is analytically different from regime building, the two processes take place at the same time during the first stage. If the newly emerging state apparatuses, such as the bureaucracy, taxation system, military, and police force, were challenged by indigenous elements such as communist insurgents or ethnic minorities, the state builders, who were simultaneously the first generation of regime builders, considered it their duty to protect the state apparatuses. They had no tolerance for challengers. In the event of challenges from those peripheries, they used violence to exterminate the challengers rather than simply teach them to obey their new-born regime's rules and orders.

It is noteworthy that the timing of independence and the ensuing state construction, paired with the initial regime building, is the most important factor. The international environment, i.e., the Cold War divide, was the key frame wherein those new states emerged. Many Asian states introduced Westernstyle uniformed military forces, and these forces led, and defended, the new state. Certainly there were internal-external interactions. Internally, the leaders of state formation tried to make their best effort to penetrate into the peripheries, disallowing federation or autonomous systems. Externally, they saw the expanded U.S. influence in Asia after the end of the Pacific War. Their vision of a new state and the image of the real world were projected in their building of the first regime. In most cases, the consequence was the conflation of state construction and authoritarian and anticommunist regime building. (Exceptions were the northern parts of Korea and Vietnam, where communists took control of power following national division. A moderate exception was Indonesia, where the leader Sukarno took a socialist path.) The regime at that initial phase was characteristically dictatorial, mostly military-based, as well as anticommunist. The communists, along with ethnic minorities, became targets for elimination by the top power. They were considered not merely political challengers but also 
a lethal threat to the establishment of the U.S.-sponsored state. This particular situation of conflation of state construction and anticommunist regime building conditioned brutal violence.

At the time of conflation of the state construction and the autocratic-regime building, political leaders of an anticommunist persuasion were in accordance with the U.S. interests. Their efforts were concentrated on the protection of state security and defending the regime against communist insurgencies. In Korea and Vietnam, two contending states and rival regimes were formed during the period of liberation and independence. Syngman Rhee in South Korea led the building of the Republic of Korea in 1948 after three years of turmoil, and the regime under his leadership was autocratic, pro-U.S., and anticommunist; many important positions in the state apparatus were filled with former supporters of the Japanese colonial regime. In 1955, Ngo Dinh Diem became the first president of the Republic of Vietnam. The regime under Diem's rule was autocratic and anticommunist and lasted for eight years with support from the United States.

One difficult question is how to define the period of state construction, and of the first regime building within that state. The process of state construction normally takes more than just a few years, sometimes more than a decade. After independence, a formal declaration of state construction was not enough. What's more, international recognition per se could not complete the process. The anticommunist counterinsurgency in Indonesia, which culminated between 1965 through 1968, exemplified a long, grueling process of state construction involving mass killings of challengers, whether perceived or real. The current ethnic conflict in Myanmar shows that the business of the state construction is still incomplete. The two cases show an extremely long process, whereas most other Asian cases had a shorter period of state construction. As noted earlier, however, the declaration of independence and the ensuing international recognition preceded the completion of internal processes of exclusion and inclusion. Despite differences in length, there was usually a certain period of rivalry among important figures and between diverse local or ethnic forces. The course of pacification of challenging forces was characterized by brutal violence such as conspired assassinations, mass killings, and massacres. In those non-democracies, it was up to the top figures to define the time when the state construction was completed. As long as they felt threatened by challenges and they legitimized the violence, the process of state construction continued. Once they were convinced that the challenging forces, viewed as being detrimental to the foundation of the statehood, were exterminated, then they might believe that state construction was complete. The establishment of the state apparatuses (the bureaucracy, tax system, and the military) was never a sign that the process of state construction was completed. If state construction was slow and protracted, the result of the competition for the control of power was likely to be bloody violence targeting the challenging forces. 
In circumstances in which state construction and the first regime building are conflated, the modality of violence is normally extreme. "Instrumental violence" is the best way to characterize this modality (Cornell et al. 1996; Boudreau 2013). Like genocide or ethnic cleansing, violence associated with the conflation of state construction and regime building is intended to root out any challenging groups. Instrumental violence is neither intended to simply teach people a lesson about the new order nor to act as a warning that disobedience will be punished. Instrumental violence intends to "neutralize or displace a threat or challenge," and thus it "directly disrupts, disaggregates, or eliminates political targets" (Boudreau 2013, 24). Instrumental violence uses every means available to eradicate those who threaten state security and the functioning of the state apparatuses.

The communist insurgencies active in the period after independence were seen as a grave threat to the forces of state construction and regime building. Counterinsurgency operations in Jeju, Korea, from 1947 to 1954 and in Indonesia between 1965 and 1968 are examples of instrumental violence that resulted in the deaths of innocent people as well as the insurgent groups (Kim 2009; Kammen 2013). The forces of state construction did not simply mop up rebels but killed anyone they perceived to be rebels or rebel sympathizers, and even neutral bystanders. Obviously there was a perception gap between the state constructors and the victims. The state constructors perceived the entire community, from which rebels or perceived rebels came, as a peripheral zone that must be suppressed in order to preserve the security of the state and the newly forming regime. But the ordinary people-whether sympathizers or neutral bystandersdid not see themselves as having anything to do with the insurgency per se. This implies a gap in perception between the perpetrators and victims about threat, order, and governance (Kim and Ganesan 2013, 8).

Regardless of their real intentions or actual participation, members of an entire community may become targets of instrumental violence. For the leaders of state construction, there is no difference between the periphery of state sovereignty and a challenger to the emerging regime's norm and legitimacy. In this circumstance, state security was considered the same as regime security. Challengers with different ideological backgrounds were frequently called "insurgents" and considered threats to statehood, as well as a contending force against the emerging regime's norms and legitimacy. The forces of state construction did not hesitate to use instrumental violence to exterminate the challengers.

Inasmuch as challengers are considered elements of fatal danger to both the newly forming state and the first-ever regime, the violence against them is highly likely to be justified for a long period of time, and a verdict on it is unlikely to be reversed later. The challengers have already disappeared from the political scene, and thus they are no longer a contender for power. The conflation of state 
construction and regime building has made the violence long forgotten and made victims and their families feel powerless. In this case, transitional justice, particularly finding truths and demanding accountability, is hard to be realized. However, if violence takes place during a certain regime's power transition, but not in conjunction with state construction, there is a chance that transitional justice takes place when the violent regime ends.

\section{Longevity of the Violent Regime}

Separately, longevity of the regime which committed the violence is another obstacle to transitional justice. A thirty-year span or one biological generation may become a baseline for dividing a long-lived regime for a short-lived regime. The biological generation is the average span of time between the birth of parents and that of their children, and the sociopolitical generation corresponds to a biological generation. As generations change over time, the new generation lives in an environment different from the parent generation, a situation that facilitates emergence of new institutions, norms, values, and memories. Counterintuitively, one generation is enough time for a violent regime to justify its brutal acts and institutionalize its powerbase that has abused human rights.

In Asia, longevity has mattered because of the long Cold War context in which most of the violence took place and it was legitimated. Just as the Cold War divide resulted in a particular form of conflation of state construction and regime building, so it justified for several decades-without transitional justice-the violence committed by the leaders who formed the state and built an anticommunist regime. The Jeju counterinsurgency in Korea, which continued from 1947 through 1954, is a prime example of a failure to realize justice for six decades, despite successive changes of regime. The Indonesian army's counterinsurgency operation in 1965-1968, which took place at a time when the Vietnam War was escalating, has yet to be investigated (Sundhaussen 1982). The dominant ideology painted the victims as deserving their miserable fate even long after the violence was ended.

Even when there was no conflation of state construction and regime building, seeking truths and subsequent demands for accountability have been avoided in some instances of violence. The long duration of the violent regime is the main reason for this. There have been no serious efforts to enquire into truths about the "red drum" massacre in Phatthalung, Thailand, which took place in the early 1970s as an anticommunist operation (Haberkorn 2013a, 2013b). A contrasting case was the 1980 Kwangju incident in Korea, which initially was depicted in the government-controlled media as a riot instigated by "impure elements." Thanks to the ensuing negotiated democratization process that started in 1987, the incident entered the stage of hearings and truth-finding in the 1990s 
(Wang 1995; Ahn 2003; Choi 2005). In both Thailand and Korea, the violence was committed by military authoritarian regimes; however, the two countries took different paths because of the difference in the length of the violent regimes and the differing characteristics of international environment.

Certainly, longevity of the regime that committed the violence or its successor regime contributes to the delay in seeking and finding truths about the violence. Olsen, Payne, and Reiter (2010) also note this point. For the power holders, the challengers to their regime might be considered the same as contenders to the state as well, not to the regime alone. As shown in the earlier examples, the so-called communist insurgents are seen as targets for elimination in order to preserve the security of both the state and the regime. Since the competitors are excluded from the power contest-not to mention the removal of ethnic minorities on the periphery-the configuration of competition in the successor regimes is kept simple. However, competition is likely to occur within the inner circle, in the form of a military coup or palace revolution. Shifts in the leadership and the replacement of those at the top do not mean changes in the relationship between the rulers and the ruled. The replacement of personnel within the leadership does not bring about change in the rules and orders of the regime that define authority relations and the means of representation. In this regard, there is no substantial change in the characteristics of the regime. The replacement of top leaders may be followed by new institutional arrangements; however, as proponents of institutionalism maintain, old institutional constraints tend to prevail over these seemingly important new arrangements (North 1990, 83-91). If the regime that committed the ruthless violence (and its successor regimes) lasts for a long period of time, it is likely that seeking truths and enquiring into accountability will be delayed even beyond democratic transition.

A long-lasting regime builds stable state apparatuses, particularly the military, the police, and the security agency. Evidence and documents are either concealed or destroyed. Impunity is the norm in these cases. In the period of transition, successor regimes, or some of their members, may admit that there was violence in the past. But they may try to argue that such violence was inevitable in order to protect the integrity of the state, and thus try to treat the victims as enemies of the regime (Philpott 2006, 17). They refuse to respond to victims' demands for public disclosure of the evidence; the magnitude of the violence in the official account will differ from that in the accounts given by victims.

Those who were not killed are often closely monitored, and their movements restricted. Those who associate with these surviving victims are labeled subversives; their behavior is viewed as detrimental to the integrity of the state. The rulers may create a new space where discussion of past violence is allowed, but it is never permitted to become a public agenda item. The existence of this regulated space not only erases memories of the violence but also delays 
resolution. A case in point is the behavior of the Chinese authorities, who have monitored discussion on social media of the 1989 Tiananmen incident, while at the same time permitting public discourse on the topic (Yang 2003; Abbott 2001; Kim and Ganesan 2013).

Whatever defense mechanisms the rulers choose, the longer the regime persists the less likely it is that past violence will become a public agenda item not only while that regime is in existence but also after democratic transition begins. This is because the old regime is able to institutionalize various aspects of its practices, including agencies of social control, personal leadership, and political exclusion (Garretón 1986, 160-63). Given this, civil society, even in an embryonic form, cannot emerge; advocacy groups cannot take root in such a society because of the regime's surveillance and suppression.

It is noteworthy that regime longevity is not always coupled with conflation of state construction and regime building. In some instances, new regimes that emerge long after the completion of state construction may also be blamed for absence of transitional justice. For example, after state construction is accomplished, a military regime may rise to power and commit violent acts and manage to keep them quiet for a long period of time. The purpose of the violence would have been either to defend the regime, to cope with regime crisis, or to consolidate the regime. In any of these cases, the violence may not easily be addressed. This is true particularly when the regime, or its successor regime, persists long enough to institutionalize safety devices. The military regime in Brazil between 1964 and 1985 is an example. The military officers who seized power did so because they believed that the country was in crisis. The urgent objectives were national security and development, which they claimed were interdependent and thus related to state security. The military regime's long duration, almost one generation, meant that the violence was ignored for years, even though it was not completely forgotten. Based on strengthened and institutionalized security agencies, the regime paved the way for a negotiated transition, and the military leaders gradually gave up their prerogatives (Stepan 1988, 103-14). Consequently, the successor regime, in the process of democratization, did not face up to past violence directly, but did so cautiously. This kind of negotiated transition took place in Korea as well. In Korea, the June 29 declaration of 1987, prepared by regime insiders, and the subsequent process of transition were based on the spirit of moderation shared by the military and the opposition forces in Korea (Bermeo 1997).

\section{Five Cases in Asia}

Democratic transition might create an environment to open opportunities for a new society to confront the wrongdoings of the previous regime. As discussed 
Table 2. Five Cases

\begin{tabular}{|c|c|c|c|}
\hline & & \multicolumn{2}{|c|}{ Conflation of State Construction and Regime Building } \\
\hline & & Yes & No \\
\hline \multirow{5}{*}{$\begin{array}{l}\text { Duration } \\
\text { of Violent } \\
\text { Regime }\end{array}$} & \multirow[t]{3}{*}{ Long } & Obstructed TJ & Unsuccessful TJ \\
\hline & & $\begin{array}{l}\text { Jeju, Korea, } 1947-54 \\
\text { (long-delayed truth-finding, but } \\
\text { impunity for perpetrators) }\end{array}$ & $\begin{array}{l}\text { Thailand, 1971-75 } \\
\text { (investigation, but impunity for } \\
\text { perpetrators) }\end{array}$ \\
\hline & & $\begin{array}{l}\text { Indonesia, } 1965-68 \\
\text { (TRC not activated yet, truth-finding } \\
\text { obstructed) }\end{array}$ & \\
\hline & \multirow[t]{2}{*}{ Short } & Unsuccessful TJ & Successful TJ \\
\hline & & $\begin{array}{l}\text { Imperial Japan, } 1945 \\
\text { (early support for war-dead, but } \\
\text { impunity for perpetrators) }\end{array}$ & $\begin{array}{l}\text { Kwangju, Korea, } 1980 \\
\text { (truth-finding, hearing, trial, } \\
\text { pardon) }\end{array}$ \\
\hline
\end{tabular}

Source: Author

above, however, democratization is not always followed by transitional justice. Even in the event of democratization, the above-mentioned two factors-stateregime building conflation and longevity of the violent regime-justify the violence. In principle, there are three types of mechanisms: amnesty, pardon, compensation, and reparation as minimalist mechanisms; truth-finding and hearings as moderate ones; and trial and imprisonment as maximalist ones (for these types, see Olsen, Payne, and Reiter 2010). The two factors rule out the possibility of the new regime's adoption of even a moderate mechanism that requires truth-finding, thus bringing about impunity for the perpetrators. There may be conflict over "competing truths" where the past is concerned, to use Arenhövel's term (Arenhövel 2008); however, the truths from victims' perspective are unlikely to win.

There is one cautionary note. The form of democratic transition, to which some analysists pay special attention (De Brito, González-Enríquez, and Aguilar 2001), has no real impact on the successor regime's way of dealing with the past violence. A violent regime may either collapse suddenly or experience gradual transition. Sudden collapse draws a line under the violence, chiefly by the removal of the people in power, whereas gradual change is based on pacts and mutual concessions between the regime in power and the opposition forces. Collapse is best exemplified by the fall of Imperial Japan and the drastic changes that took place in Eastern Europe, whereas examples of gradual transition include the democratization process in Korea and to some extent Thailand and Indonesia. However, whatever the form of the transition may be, the conflation of state construction and regime building and the longevity of the violent regime are the determinants to prohibit a society in transition from seeking truths about 
past violence and holding the perpetrators accountable. In this case, impunity is normal for the perpetrators (see Table 2).

\section{Indonesia}

The Indonesian counterinsurgency operation was an example of instrumental, categorical violence that took place at a time when the protracted state-building process was accompanied by anticommunist regime building. Sukarno declared independence in August 1945, thus launching the process of state construction; however, the Netherlands tried to reinstate its power, and conflict ensued until they formally recognized the independence in December 1947. Indonesia also encountered difficulties politically in the process of integrating its vast territory and diverse social groups-consisting of six thousand inhabited islands and hundreds of ethnic groups. It is notable that the construction of the state was protracted, taking two decades following independence. The important state apparatus, particularly the military, was not under the control of the top leader. Coinciding with a gradual decline in Sukarno's power and a shift of power to General Suharto, the counterinsurgency operation carried out by the army and the anticommunist militia continued from 1965 through 1968. The operation mopped up members of the Indonesian Communist Party and their sympathizers, many of whom were perceived enemies rather than real insurgents. The number of victims reached a million, and the counterinsurgency used instrumental violence, not to teach them a lesson but to root them out (International Center for Transitional Justice and KontraS 2011). The attack on the communists was carried out under loose and divided military leadership and it developed into a broader attack by General Suharto on Sukarno and Sukarnoism (Kammen 2013, 179-80). It is fair to say that the waves of violence that swept the archipelago were part of the extended state-construction process. This state construction was conflated with the rise and consolidation of the anticommunist regime. In the eyes of the army and its allies, the regions and communities where communists and their collaborators prevailed were a periphery that needed to be eradicated (McGregor 2009). For Suharto's army and its affiliates, the counterinsurgency operation was a fight for legitimacy and integrity of the foundation of the state as well as the anticommunist regime.

The end of the violent regime in 1998 and the subsequent, gradual change to democracy over the course of two decades has not been followed by a meaningful initiative by the new regime to inact truth-finding and accountability regarding the mass killings in the 1960s. Suharto stepped down in May 1998, and after that human rights advocacy groups lobbied the transitional regime under Habibie, Wahid, and Megawati to introduce the Law on the Truth and Reconciliation Commission (TRC), which was eventually passed in 2004. But the Constitutional Court ruled the TRC law unconstitutional, a decision that was clearly political rather than legal. Furthermore, despite efforts by international and domestic 
advocacy groups to get the post-Suharto regime to enquire into truths, progress was blocked by a systematic unwillingness to unearth the truth about the past. The truth-finding enquiries have been obstructed by the return to power of former security officials and the appointment of individuals who lack objectivity (International Center for Transitional Justice 2005; International Center for Transitional Justice and KontraS 2011).

It is worth noting that the conflation of state construction and regime building is not the only reason for the failure to enquire into truths and accountability. This failure should be attributed to the longevity of the Suharto regime (1967-1998) as well. Suharto's three-decade-long rule, which began at a time of escalating conflict in Indochina and extended into the post-Cold War period, contributed to the institutionalization of the security apparatus which protected the perpetrators of the atrocities, despite calls for justice from the victims and advocacy groups. The gradual and negotiated transition to democracy has been successful, but the longevity of the old regime has rendered even a moderate mechanism such as truth-finding and reconciliation unworkable.

\section{Korea}

The two cases in Korea-the violent suppression in Jeju (1947-1954), and the Kwangju incident (1980) - are contrasting examples of confronting past violence in one country. First of all, the Jeju incident was a typical case of violence perpetrated during the period of conflation of state construction and regime building. The violent regime and its successor regimes persisted long enough for public memories of the event to fade. The main instigators and perpetrators of the bloody operation, or those who held important posts in the military or the civilian administration under the authoritarian regime, were dead by the time Korea embarked upon democratization in 1987. For more than fifty years, the mass killing was viewed as a legitimate military operation aimed to suppress communist insurgents who challenged the foundation of the new state and its government (Kim 2009; Huh 2010, 2011).

The Jeju incident began with police opening fire on civilians in March 1947, at a time when the U.S. Military Government in Korea was supporting the conservative and anticommunist political figures in Syngman Rhee's circle who were preparing to establish the Republic of Korea (South Korea). The mass killing occurred in 1948 when the National Constabulary was conducting a mopup operation on Jeju Island to root out communists, their family members, and so-called sympathizers. The communist insurgents were trying to obstruct the general election scheduled for May for the composition of the constitutional national assembly; however, many people with no such political agenda became victims. With the outbreak of the Korean War (1950-1953), many more civilians again became the target of violence perpetrated by the army and the police. The dead and the missing numbered twenty-five to thirty thousand (Huh 2010, 285). 
The formal truth-finding mechanism regarding the Jeju incident ended up with a symbolic reconciliation without any concrete measure of accountability. With the passing of the Special Law for Truth-finding and Honoring the Victims of the Jeju April 3 Incident in 2000, these events were given a new interpretation-"an incident in which civilians were victimized amid armed clashes and operations" (Article 2 of the Law) rather than the suppression of a communist insurgency. The truth-finding committee began the work of restoring the good name of the victims and established a peace park on the island in their honor. In 2003, President Roh Moo-hyun apologized to the victims for the abuse of state power at the time of the incident. But the truth-finding law itself failed to authorize the committee to investigate the perpetrators and provide victims and their families with reparations. Democratization and the process of democratic consolidation helped to uncover the past violence, but the conflation of state construction and regime building and the lengthy duration of the authoritarian regime brought about impunity for the perpetrators. Most witnesses had already passed away, and those organizations that were involved in the violence still exercised influence over the committee (Kim 2014, 252-55).

In contrast to the Jeju case, the short duration of the violent military regime, which committed killings in in May 1980 in Kwangju, contributed to achieving full scale transitional justice. The incident took place when a new military regime rose to power, but it was not conflated with state construction in Korea. After achieving transitional justice, the events of May 18, 1980 in Kwangju are now remembered as a democratic movement. Right after the assassination of general-turned-president Park Chung-hee in 1979, the new group within the army centered on Major General Chun Doo-hwan led a mutiny aimed at seizing control of the army. In the following year, this group set about suppressing critics and expanded its power and eventually carried out indiscriminative killings in Kwangju. The consolidation of Chun's military regime had nothing to do with the protection of the foundation of the state, even though the regime called the situation a state emergency and branded the protesters as "impure elements" (Jameson 2000, 84). As the military regime faced strong opposition from the alliance of citizens and opposition party leaders, Chun Doo-hwan and his colleague Roh Tae-woo gradually transferred power to civilians through a twostep process: first, a negotiated pact in 1987, and then a full transfer of authority to a civilian politician, Kim Young-sam, after the 1992 presidential election. Transitional justice with regard to the May 18 violence used a combination of diverse mechanisms-including reparations, trials, hearings, and amnesty. This is a model case of hybrid transitional justice. It proceeded peacefully with little intimidation by members of the old order or any back pedaling.

\section{Thailand}

The brutal burning alive of civilians in the "red drum" (old oil drum) in Thailand's 
Phatthalung Province between 1971 and 1975 was covered up for three decades. The red drum killings were brought to public attention only after the death of the military dictator Thanom Kittikachom in 2003. The longevity of the violent military regime (three decades) has left the case unresolved even after the country started incremental changes toward democracy. The red drum violence did not take place in the context of conflation of state construction and regime building, but it was a consequence of an anticommunist military regime's repression of communist sympathizers and innocent villagers at the height of conflict in Indochina. Indeed, the Thanom regime was one of a series of military regimes that held power under the Thai constitutional monarchy, which was inaugurated in 1932, and the regime's offence was for the purpose of maintaining the order of anticommunist military rule.

Research based on U.S. archival sources reveals that General Sant Chitpatima, the commander of the Fifth Military Circle and the regional commander in charge of the Mid-South Region, was responsible for the killings. This study also revealed that the United States was aware of the brutal crackdown on the villagers. The Thai military command used the Vietnam War as justification for the brutal anticommunist operation, while the United States kept silent and allegedly even supported it (Zipple 2014, 98-101). Most of the civilian victims were branded communist terrorists or their supporters. They were victims of armed clashes between the army and the then illegal Communist Party of Thailand $(\mathrm{CPT})$, as one survivor testifies:

What can villagers like us do when we are sandwiched between the government officials and the CPT? If we refused to cooperate with either side we would be in great danger. Taking sides with the CPT seemed to be the best way to survive in the circumstances when the police and security officers could not provide us with protection and everything was a real mess (Bangkok Post Special Publication 2003).

The red drum killings in Thailand have certain things in common with the Jeju incident in Korea and the counterinsurgency in Indonesia. A major difference is that in the Korean and Indonesian cases, instrumental violence was used at a time of conflation of state construction and regime building, whereas the red drum killings were intended to teach the villagers an anticommunist lesson. In terms of modality, the red drum killings were not an example of instrumental violence that is normally aimed at exterminating the entirety of the targeted group.

Because of the subsequent absence of serious investigation and truth-finding measures, General Sant and the other alleged perpetrators got away with the massacre of about 3,000 people. During a brief period of democracy from 1973 to 1976, members of a pro-democracy group, the Student Federation of Thailand, visited the villages concerned and tried to collect information. The army 
disrupted the fact-finding activity, and the victims' relatives were too afraid to speak out. Even after the media highlighted the killings in 2003, the government under democratic transition was still unwilling to carry out a serious investigation and instead continued to justify the killings as an anticommunist operation (Haberkorn 2013a). Even during the democratization process, both the violent military's power during the long Cold War divide and its enduring influence in politics, which was due to its loyalty to the monarchy, were the primary reason for the absence of transitional justice with regard to military-led violence.

\section{Japan}

The killings of Okinawans by the Japanese army took place during the final stage of the Pacific War, and defeat in that war triggered the collapse of the regime and political transition (De Brito, González-Enríquez, and Aguilar 2001, 11). Although the postwar democratic government might have been assumed to have an opportunity to investigate the incident, the Okinawa killings did not become a public agenda item for the entire duration of the Cold War. The presence of the U.S. military administration from 1945 to 1972 and the continued presence of U.S. forces since then delayed the emergence of an Okinawan identity. The security of Japan and its alliance with the United States were the most important issues for anticommunist policymakers. The Okinawan case is another example of the negative impact of the Cold War divide on the thorough resolution of violence perpetrated by the state on its own citizens. The government's reparation scheme in the 1950s distorted memories of the Okinawa incident. Only victims who acknowledged that the violence had been carried out in the service of national defense were able to receive war reparations. In this context, deaths at the hands of the Imperial Army were interpreted as a heroic sacrifice for their country; there were no perpetrators or victims of state violence. To make matters worse, since the 1980s, the government's revisionist interpretation of the incident depicts it as a case of "mass suicide." According to the official version, there was no stateled violence at all (Nozaki 2008).

In sum, Imperial Japan's violence on its own citizens was committed in the name of preserving the foundation of statehood centered on Emperor Hirohito. The rise of the postwar democratic regime meant a break from the wartime regime, but the survival of the state per se and the rehabilitation of the former wartime politicians at the height of Cold War meant continuity of statehood passing through wartime and postwar periods. Given this situation, postwar Japan treated the Okinawan victims as wartime dead and servants of the state, and made the refusal of truth-finding and provision of impunity to perpetrators inevitable. 


\section{Conclusion}

This article has addressed the question of why some cases of state violence against citizens in Asia are not followed by a process of enquiring into truths and demanding accountability even during a democratic transition. It has shown, first, the conflation of state construction and regime building impedes that process. Victims of violence in this circumstance are normally ignored long after the violence has taken place, and the perpetrators get off scot-free. When the violence is taking place, victims are regarded as part of the periphery and a threat to state security, and as such they are legitimate targets for elimination through instrumental violence. After the violence, their associates and sympathizers are monitored by the regime in power. With institutionalized security agencies, the new regime in transition provides impunity to the alleged perpetrators even in the case of adopting truth-finding procedures. Second, the longevity of the regime that committed the violence and its successor regimes-even in the absence of a conflation of state construction and regime building — tends to hinder attempts to seek truths and accountability about the past even during a democratic transition.

Additionally, this article has shown that the form of the political transition, whether negotiated gradual transition or sudden collapse, does not really matter at the bifurcation point, whether seeking truths or giving impunity to perpetrators. Of the five cases, the Kwangju incident provides a model of successful transitional justice: gradual progress without social division, and a combination of minimalist, moderate, and maximalist mechanisms. I underscore that the success should not be attributed to the gradual political transition, but to the short lifespan of the violent regime.

\section{Acknowledgments}

The author acknowledges that the idea of this exploratory task can be traced back to work in 2013 with N. Ganesan, who has been insightful and provided helpful suggestions throughout the research. Also, the author expresses deep gratitude to Janjira Sombatpoonsiri, Carlos Fernandez Torne, and the two anonymous reviewers for their critical, helpful comments and to the support of National Research Foundation of Korea-Grant funded by the Korean Government (NRF2010-361-A00017).

\section{References}

Abbay, Alemseged. 2004. "Diversity and State-Building in Ethiopia." African Affairs 103 (413): 593-614. 
Abbott, Jason P. 2001. “Democracy@internet.asia? The Challenges to the Emancipatory Potential of the Net: Lessons from China and Malaysia." Third World Quarterly 22 (1): 99-114.

Ahn, Jong-chul. 2003. "Simin'gun: The Citizens' Army during the Kwangju Uprising." In Contemporary Kwangju: The May 18 Uprising in Korea's Past and Present, eds. GiWook Shin and Kyung Moon Hwang. Lanham, MD: Rowman \& Littlefield, 11-21.

Abu-Nimer, Mohammed, ed. 2001. Reconciliation, Justice, and Coexistence: Theory and Practice. London: Lexington Books.

Amstutz, Mark R. 2006. "Restorative Justice, Political Forgiveness, and the Possibility of Political Reconciliation.” In Politics of Past Evil: Religion, Reconciliation, and the Dilemmas of Transitional Justice, ed. Daniel Philpott. Notre Dame, IN: University of Notre Dame Press, 151-88.

Arenhövel, Mark. 2008. “Democratization and Transitional Justice." Democratization 15 (3): 570-87.

Ashworth, Andrew. 2002. "Responsibilities, Rights and Restorative Justice." British Journal of Criminology 42 (3): 578-95.

Aspinall, Edward, and Mark T. Berger. 2001. “The Break-Up of Indonesia? Nationalisms after Decolonisation and the Limits of the Nation-State in Post-Cold War Southeast Asia." Third World Quarterly 22 (6): 1003-24.

Bangkok Post Special Publication. 2003. "Red Drum Massacres of 30 Years Ago-Oct 14, 1973-People's Progress, 30 Years On.” October 14. http://asiaprovocateur.blogspot. kr/2014/06/roasting-people-alive-thai-armys-red.html (accessed July 5, 2019).

Bell, Vikki, and Kirsten Campbell. 2004. "Out of Conflict: Peace, Change and Justice." Social and Legal Studies 13 (3): 299-304.

Bermeo, Nancy. 1997. "Myths of Moderation: Confrontation and Conflict during Democratic Transitions." Comparative Politics 29 (3): 305-22.

Boraine, Alexander L. 2006. “Transitional Justice: A Holistic Interpretation.” Journal of International Affairs 60 (1): 17-27.

Boudreau, Vince. 2013. “Interpreting State Violence in Asian Setting." In State Violence in East Asia, eds. N. Ganesan and Sung Chull Kim. Lexington: University Press of Kentucky, 19-46.

Cho, Kuk. 2007. “Transitional Justice in Korea: Legally Coping with Past Wrongs after Democratization." Pacific Rim Law \& Policy Journal 16 (3): 579-611.

Choi, Jungwoon. 2005. The Gwangju Uprising: The Pivotal Democratic Movement that Changed the History of Modern Korea. Paramus, NJ: Homa \& Sekey Books.

Clarke, Meghan. 2009. "Polarization: The Role of Emotions in Reconciliation Efforts." Law \& Contemporary Problems 72 (2): 27-31.

Cole, Juan R. I., and Deniz Kandiyoti. 2002. "Nationalism and the Colonial Legacy in the Middle East and Central Asia: Introduction." International Journal of Middle East Studies 34 (2): 189-203.

Cornell, Dewey G., Janet Warren, Gray Hawk, Ed Stafford, Guy Oram, and Denise Pine. 1996. "Psychopathy in Instrumental and Reactive Violent Offenders." Journal of Consulting and Clinical Psychology 64 (4): 783-90.

Cribb, Robert, ed. 1990. The Indonesian Killings, 1965-1966: Studies from Java and Bali. Clayton, Victoria: Centre of Southeast Asian Studies, Monash University.

Dassin, Joan R. 1979. “A Report on Human Rights in Brazil: A Report as of March 1979.” 
Universal Human Rights 1 (3): 35-49.

De Brito, Alexandra Barahona, Carmen González-Enríquez, and Paloma Aguilar. 2001. Politics of Memory: Transitional Justice in Democratizing Societies. Oxford: Oxford University Press.

Duthie, Roger. 2009. "Building Trust and Capacity: Civil Society and Transitional Justice from a Development Perspective." International Center for Transitional Justice, New York.

Fernandez-Torne, Carlos. 2017. "How Truth Commissions Promote Accountability: An Evaluation of impact of the Commissions Established in Nepal and Sri Lanka." PhD diss., Universitat Autonoma de Barcelona.

Garretón, Manuel Antonio. 1986. "Political Processes in an Authoritarian Regime: The Dynamics of Institutionalization and Opposition." In Military Rule in Chile: Dictatorship and Oppositions, eds. J. Samuel Valenzuela and Arturo Valenzuela. Baltimore: Johns Hopkins University Press, 144-83.

Haberkorn, Tyrell. 2013a. "Getting away with Murder in Thailand: State Violence and Impunity in Phatthalung." In State Violence in East Asia, eds. N. Ganesan and Sung Chull Kim. Lexington: University Press of Kentucky, 185-208.

Haberkorn, Tyrell. 2013b. "Tracing an Uneven History: Notes on Sources and Trajectories of Thai State Violence." Asian Journal of Peacebuilding 1 (1): 109-16.

Hamber, Brandon. 1998. "Living with the Legacy of Impunity: Lessons for South Africa about Truth, Justice and Crime in Brazil." Latin American Report 13 (2): 4-16.

Hirsch, Michal Ben-Josef. 2014. "Ideational Change and the Emergence of the International Norm of Truth and Reconciliation Commissions." European Journal of International Relations 20 (3): 810-33.

Huh, Ho-Joon. 2010. "State-Making and Civilian Killings during the Period of the Formation of the Cold War: Comparison between Jeju 4.3 Uprising and Greek Civil War" [in Korean]. Ph.D. diss., Jeju National University.

Huh, Ho-Joon. 2011. "The Experience and Recognition of U.S. Military Advisors about Jeju 4.3." [In Korean]. Democracy and Human Rights 11: 283-319.

International Center for Transitional Justice. 2005. "Comment by the International Center for Transitional Justice on the Bill Establishing a Truth and Reconciliation Commission in Indonesia." https://www.ictj.org/publication/comment-ictj-billestablishing-truth-and-reconciliation-commission-indonesial (accessed August 27, 2019).

International Center for Transitional Justice and KontraS. 2011. Derailed: Transitional Justice in Indonesia since the Fall of Soeharto. https://www.ictj.org/sites/default/files/ ICTJ-Kontras-Indonesia-Derailed-Summary-2011-English.pdf (accessed July 5, 2019).

Jackson, Robert H., and Carl G. Rosberg. 1982. "Why Africa's Weak States Persist: The Empirical and the Juridical in Statehood." World Politics 35 (1): 1-24.

Jameson, Sam. 2000. "Reflections on Kwangju." In The Kwangju Uprising: Eyewitness Press Accounts of Korea's Tiananmen, eds. Henry Scott-Stokes and Lee Jae Eui. New York: M. E. Sharp, 77-86.

Jeffery, Renée, and Hun Joon Kim. 2014. "Introduction: New Horizons: Transitional Justice in the Asia-Pacific." In Transitional Justice in the Asia-Pacific, eds. Renée Jeffery and Hun Joon Kim. Cambridge: Cambridge University Press, 1-31. 
Kammen, Douglas. 2013. "Counterrevolutionary Violence in Indonesia." In State Violence in East Asia, eds. N. Ganesan and Sung Chull Kim. Lexington: University Press of Kentucky, 159-84.

Kim, Hun Joon. 2009. "Seeking Truth after 50 Years: The National Committee for Investigation of the Truth about the Jeju 4.3 Events." International Journal of Transitional Justice 3 (3): 406-23.

Kim, Hun Joon. 2012. "Structural Determinants of Human Rights Prosecutions after Democratic Transition." Journal of Peace Research 49 (2): 305-20.

Kim, Hun Joon. 2014. "Transitional Justice in South Korea." In Transitional Justice in the Asia-Pacific, eds. Renée Jeffery and Hun Joon Kim. Cambridge: Cambridge University Press, 229-57.

Kim, Sung Chull, and N. Ganesan. 2013. "Introduction: Conceiving State Violence, Justice, and Transition in East Asia." In State Violence in East Asia, eds. N. Ganesan and Sung Chull Kim. Lexington: University Press of Kentucky, 1-18.

Kritz, Neil J., ed. 1995. Transitional Justice: How Emerging Democracies Reckon with Former Regimes, Volume I: General Considerations. Washington, D.C.: USIP Press.

Lundy, Patricia, and Mark McGovern. 2008. "Whose Justice? Rethinking Transitional Justice from the Bottom up." Journal of Law and Society 35 (2): 265-92.

Lutz, Ellen L., and Caitlin Reiger. 2009. “Conclusion.” In Prosecuting Heads of State, eds. Ellen L. Lutz and Caitlin Reiger. Cambridge: Cambridge University Press, 275-93.

Mamdani, Mahmood. 2001. "Beyond Settler and Native as Political Identities: Overcoming the Political Legacy of Colonialism." Comparative Studies in Society and History 43 (4): 651-64.

Marshall, Tony F. 1999. Restorative Justice: An Overview. London: Home Office.

McGregor, Katherine E. 2009. "Confronting the Past in Contemporary Indonesia: The Anti-Communist Killings of 1965-66 and the Role of the Nahdlatul Ulama." Critical Asian Studies 41 (2): 195-224.

Mengisteab, Kidane. 1997. "New Approaches to State Building in Africa: The Case of Ethiopia's Ethnic-Based Federalism." African Studies Review 40 (3): 111-32.

North, Douglas. 1990. Institutions, Institutional Change and Economic Performance. Cambridge: Cambridge University Press.

Nozaki, Yoshiko. 2008. War Memory, Nationalism and Education in Postwar Japan, 1945-2007: The Japanese History Textbook Controversy and Ienaga Saburo's Court Challenges. London and New York: Routledge.

Olsen, Tricia D., Leigh A. Payne, and Andrew G. Reiter. 2010. Transitional Justice in Balance: Comparing Processes, Weighing Efficacy. Washington, D.C.: United States Institute of Peace Press.

Parent, Geneviève. 2010. "Reconciliation and Justice after Genocide: A Theoretical Exploration." Genocide Studies and Prevention 5 (3): 277-92.

Philpott, Daniel. 2006. "Beyond Politics as Usual: Is Reconciliation Compatible with Liberalism?" In Politics of Past Evil: Religion, Reconciliation, and the Dilemmas of Transitional Justice, ed. Daniel Philpott. Notre Dame, IN: University of Notre Dame Press, 11-44.

Peou, Sorpong. 2014. “The Limits and Potential of Liberal Peacebuilding for Human Security." Asian Journal of Peacebuilding 2 (1): 37-60.

Skaar, Elin. 1999. “Truth Commissions, Trials - Or Nothing? Policy Options in Democratic 
Transitions." Third World Quarterly 20 (6): 1109-28.

Sriram, Chandra Lekha. 2007. "Justice as Peace? Liberal Peacebuilding and Strategies of Transitional Justice." Global Society 21 (4): 579-91.

Stepan, Alfred. 1988. Rethinking Military Politics: Brazil and the Southern Cone. Princeton: Princeton University Press.

Sundhaussen, Ulf. 1982. The Road to Power: Indonesian Military Politics, 1945-1967. Oxford: Oxford University Press.

Teitel, Ruti G. 2003. “Transitional Justice Genealogy.” Harvard Human Rights Journal 16: 69-94.

Verdeja, Ernesto. 2009. Unchopping a Tree: Reconciliation in the Aftermath of Political Violence. Philadelphia: Temple University Press.

Vinjamuri, Leslie, and Jack Snyder. 2004. "Advocacy and Scholarship in the Study of International War Crime Tribunals and Transitional Justice." Annual Review of Political Science 7 (1): 345-62.

Wang, Shujen. 1995. "Ideology and Foreign News Coverage: Propaganda Model ReExamined." Asian Journal of Communication 5 (1): 110-25.

Yang, Guobin. 2003. "The Co-evolution of the Internet and Civil Society in China." Asian Survey 43 (3): 405-22.

Young, Crawford. 2004. "The End of the Post-Colonial State in Africa? Reflections on Changing African Political Dynamics.” African Affairs 103 (4): 23-49.

Zipple, Matthew. 2014. “Thailand's Red Drum Murders through an Analysis of Declassified Documents." Southeast Review of Asian Studies 36: 91-111.

Sung Chull Kim is Humanities Korea Professor at the Institute for Peace and Unification Studies at Seoul National University. He has widely written on the topics of security and peace studies: alliances, nuclear nonproliferation and deterrence, state violence, and disaster and peace. He is currently working on a book manuscript on the political impact of China's economic advancement on its small neighbors. Kim has recently published two books: Partnership within Hierarchy: The Evolving East Asian Security Triangle (State University of New York Press 2017, single authored) and North Korea and Nuclear Weapons: Entering the New Era of Deterrence (Georgetown University Press 2017, coedited).Email: kim239@snu.ac.kr. 